\title{
A!
}

This is an electronic reprint of the original article.

This reprint may differ from the original in pagination and typographic detail.

Hannula, Otso; Harviainen, J. Tuomas

\section{User satisfaction with organizational learning time-efficiency in Topaasia Cards}

\section{Published in:}

Simulation Gaming. Applications for Sustainable Cities and Smart Infrastructures - 48th International Simulation and Gaming Association Conference, ISAGA 2017, Revised Selected Papers

DOI:

10.1007/978-3-319-91902-7_10

Published: 01/01/2018

Document Version

Peer reviewed version

Please cite the original version:

Hannula, O., \& Harviainen, J. T. (2018). User satisfaction with organizational learning time-efficiency in Topaasia Cards. In Simulation Gaming. Applications for Sustainable Cities and Smart Infrastructures - 48th International Simulation and Gaming Association Conference, ISAGA 2017, Revised Selected Papers (pp. 103-109). (Lecture Notes in Computer Science (including subseries Lecture Notes in Artificial Intelligence and Lecture Notes in Bioinformatics); Vol. 10825 LNCS). SPRINGER. https://doi.org/10.1007/978-3-319-91902-7_10

This material is protected by copyright and other intellectual property rights, and duplication or sale of all or part of any of the repository collections is not permitted, except that material may be duplicated by you for your research use or educational purposes in electronic or print form. You must obtain permission for any other use. Electronic or print copies may not be offered, whether for sale or otherwise to anyone who is not an authorised user. 
This is a so called personal version (author's manuscript as accepted for publishing after the review process but prior to final layout and copyediting) of the article.

Hannula O., Harviainen J.T. (2018) User Satisfaction with Organizational Learning Time-

Efficiency in Topaasia Cards. In: Lukosch H., Bekebrede G., Kortmann R. (eds) Simulation

Gaming. Applications for Sustainable Cities and Smart Infrastructures. ISAGA 2017. Lecture

Notes in Computer Science, vol 10825. Springer, Cham

https://doi.org/10.1007/978-3-319-91902-7_10

Readers are kindly asked to use the official publication in references. This version is stored in the Institutional Repository of the Hanken School of Economics, DHanken.

\title{
User Satisfaction with Organizational Learning Time-Efficiency in Topaasia Cards
}

\author{
Otso Hannula ${ }^{1}$, J. Tuomas Harviainen ${ }^{2}$ \\ ${ }^{1}$ Aalto University, Finland, ${ }^{2}$ Hanken School of Economics, Finland
}

\begin{abstract}
This paper discusses the ways in which design games are used as scaffolds for knowledge creation. Using players' reports on time-efficiency in deployments of Topaasia Cards, it demonstrates that play appears to foster creative dialogue and meaningful interaction that lead to user experiences of positive organizational knowledge creation.
\end{abstract}

Keywords: Design games; Knowledge creation; Organizational learning; User experience research.

\section{Introduction}

This paper discusses design games as a method for knowledge creation necessary for developing practices and organizational processes by providing a space for playful creativity. Although playfulness and creativity have been linked in organizational life [13] and many solutions to foster playful activities in organizational contexts have been created (e.g. [8]; [15]), the use of service design games for organizational learning remains an understudied area.

In this paper we begin this inquiry by discussing design games, an existing tradition of applying games in organizations, and describe how they foster playfulness and creativity for organizational learning. We propose that design games increase creative thinking in discussions about current working practices and thereby contribute to knowledge creation.

To achieve this end, we use a case example to examine two research questions:

RQ1: How do design games foster creative discussion for organizational learning?

RQ2: How are such tools perceived by their players? 
To answer these questions, we first introduce service design games as organizational learning tools.

\section{Design Games as Creative Interventions}

Design games are a method of participatory design which uses game rules and material to serve different interests in the design process. They are a loose group of structured, often somewhat shallow forms of play, conducted for service innovation, improvement, or knowledge creation [9]. No exact definition of design games exists, and as a phenomenon they tend to be defined more by their context than with any specific game properties [5]. Yet they have been documented as being highly efficient for the purposes of facilitating collaboration, because they enable the sharing of experiences [2]; [16]. A design game may just as well be a card game, a role play, a physical exercise, or something digital. This flexibility, together with their shallow structures, together enables designers to easily tailor the games for various organizations' and stakeholders' needs [9].

According to the seminal Play framework of Vaajakallio [15], the use of design games can best be understood through three perspectives. For the designer, the game is a tool for gathering input from a number of participants in an organized manner. For the player, it is a mind-set that allows associative and representational thinking across space and time. Finally, for the designer of a particular design game, the game forms a structure for creating materials and roles for the participants [15]; [16].

The Play framework implies that for the designer the playfulness and creativity in design games exist in service to the design process. Design games organize dialogue and collect contributions from multiple participants, and promote exploration at the expense of negotiation or compromise [2]. This means that as a whole, design games' potential as an organizational learning intervention has been left underexplored. Especially design games applied in service design have been used to interrupt routines and focus on building new understanding [10].

Design games work on principles of expansive learning (as per [3]) and the development of practices through shared discourses [6]. According to expansive learning, the development of practices takes place when the members of a community identify contradictions in their collective activity and respond to the contradictions by reorganizing their activity [4]. Mainemelis and Ronson [13] have studied the role of playfulness in fostering creativity in organizations, and identified five creativity-relevant cognitive processes supported by play: problem framing, divergent thinking, mental transformations, practice with alternative solutions, and evaluative ability. Design games aim to support all of these, by fostering discourses and thinking patterns that enable creativity, exploration, problem-forming, while giving each player a level field to propose ideas and evaluate those proposed by others [15]. Our case example Topaasia Cards focuses on precisely this kind of discussion support.

\section{Case Topaasia Card}

Our case example, Topaasia Cards, is designed and sold by Finnish company Gälliwashere. Topaasia is a family of organizational learning games which combine a dialogue for developing 
practices (as per [7]) and simple game rules which structure the discussion on shared topics and provide some competitiveness to the interaction. Topaasia Cards can be played without a facilitator and the game is intended to be played multiple times over a period of time for continuous reflection. Different decks, such as "Sales" or "Projects", are available.

In Topaasia Cards (Figure 2), players choose a topic of discussion for each round, and play a card from their hands. Each card has a suit which corresponds to a theme of development within the game, as well as a keyword which refers to a specific item of development. The selected cards are shuffled to hide which player chose which card, and the group decides which card is the most important one. That card is then moved aside together with the chosen topic marker. Out of those, at the end, the most pressing issue is selected for further development. One game usually takes from 30 to 45 minutes of play, and is able to optimally accommodate four to eight players.

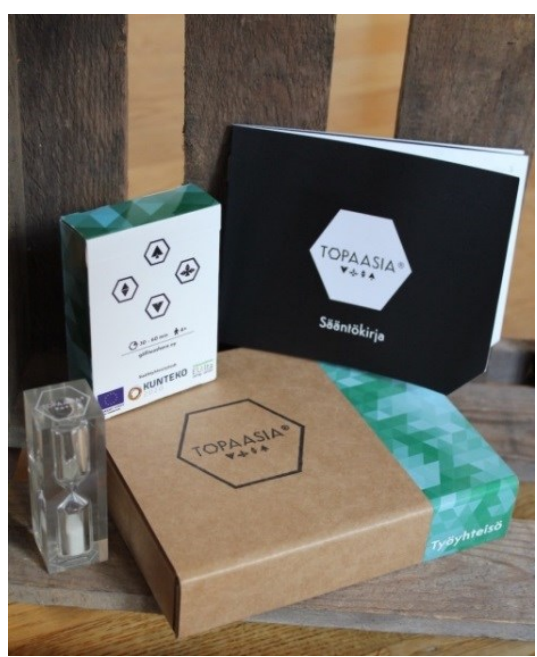

Figure 2. A Topaasia Cards deck, rulebook, package and hourglass timer. (Gälliwashere)

In order to facilitate a dialogue on developing practices, the game uses cards act as shared points of reference. The text on the card acts as a trigger for the player to consider each card's potential significance, and each player's best cards are further discussed once the cards have been played. The downside of this is that some key topics may not come up for discussion because that particular card was not played during the game. To manage this risk, best results are acquired from multiple rounds played either simultaneous or by the same group over time.

A key feature of Topaasia Cards at the time of this research the goal of getting the most points by playing cards that will be picked the best by the group. Because of this competition, the game 
might be perceived as more engaging than design games without competitive elements or clear winners (e.g., [8]).

\section{Data}

Our data set comes directly from the producing company, Gälliwashere. After each session, the players could choose to use the feedback system, Kiteyttäjä, to provide a summary of their play and provide data for the game designers. Different versions of the feedback system have included questions related to development suggestions, usefulness, etc., but we have focused our analysis to the five questions present in all submitted feedback, presented in Table 2.

\section{Table 1 - Feedback questions of Topaasia Cards (translated by Harviainen)}

\begin{tabular}{l} 
How useful was the session, compared to the time you used (1=No benefit compared to time; \\
$3=$ Equally useful compared to time [as other methods]; $5=$ Produced significantly more value \\
compared to time.) \\
\hline How well was the play session organized on a scale of $1-5$, with 5 being the best? \\
\hline Do you have suggestions on how the session could have been improved? \\
\hline What functioned well in the session? \\
\hline Other feedback?
\end{tabular}

At the time of writing this paper, Topaasia Cards been played over 300 times in over 100 companies. Exact numbers are not available because of the voluntary nature of the feedback system. A total of 53 answers were received from play sessions with an older version of Kiteyttäjä (January 1, 2015 to May 12, 2016) and 54 with a newer one (May 13, 2016 to August 19, 2016).

\section{Results}

Gälliwashere gathered evaluations for each game session with the instructions that the answers should be determined by group consensus after the play session. The average time-effectiveness evaluation was $3.74(n=53)$ for the older version and $3.78(n=54)$ for the new version. Neither data set contained any ratings of 1 (the lowest), and only one rating of 2 each. A total of 28 answers rated the sessions with an evaluation of 3 , denoting that the session in question was perceived to be as time-effective for organizational learning as other methods. 66 gave a rating of 4 , for somewhat more time-effective, and 10 gave a rating of 5, meaning extremely useful. The last 25 ratings were all 4 or above, which suggests that the iterative design may be improving its performance rate (see Table 2).

Table 2 - Summaries of user group feedback on time-efficiency

\begin{tabular}{|l|c|c|c|c|c|}
\hline & Useless & & $\begin{array}{c}\text { As } \\
\text { useful }\end{array}$ & & $\begin{array}{c}\text { More } \\
\text { useful } \\
\end{array}$ \\
\hline $\mathbf{1}$ & $\mathbf{2}$ & $\mathbf{3}$ & $\mathbf{4}$ & $\mathbf{5}$ \\
\hline Old Kiteyttäjä & 0 & 1 & 17 & 30 & 5 \\
\hline
\end{tabular}




\begin{tabular}{|l|l|l|l|l|c|}
\hline New Kiteyttäjä & 0 & 1 & 11 & 36 & 5 \\
\hline TOTAL & 0 & 2 & 28 & 66 & 10 \\
\hline
\end{tabular}

Although the available data does not allow for deep analysis, we can see that the consistent majority (71\%) of Gälliwashere clients perceived that the play was more useful for organizational learning than other methods they had tried. Given how difficult it is to convince corporate clients to see cost-effective benefits in play, we find this significant, especially since many clients have continued using the game after the initial workshops in which it was introduced. So while part of "work", the play still also seems to preserve a voluntary aspect to it as well (see e.g., (11]), especially given the high approval ratings. It appears that a combination of playful engagement, competition, and constant reflection is able to lead to organizational learning - or at least the experience that organizational learning is taking place.

It must be noted, however, that Topaasia play seems to be quite backcasting-oriented. This is not necessarily a bad thing: the identification of existing challenges, risks and potentials through the examination of present data is a key advantage of organizational gaming. Topaasia Cards thus provides important insight on the current state of the organizations within which it is played.

While user satisfaction is no gauge for organizational learning, we believe that its correlations with existing findings on knowledge creation point to there being actual benefits in this sort of play. We next turn to those correlations.

\section{Discussion and Conclusions}

According to Tsoukas [14], organizational knowledge creation takes place in dialogues, but all dialogues are not equally useful for that purpose. Dialogue has to be productive and therefore requires a type of commitment and engagement in which participants relate to each other and make it obvious that they want to work together. The participants have to separate themselves from the organization's existing practices in order to reflect on them, while still remaining aware of existing practices to create relevant knowledge. However, should participants try and protect their own interests by engaging in calculated participation at the expense of productive dialogue, knowledge creation and transfer fail.

We believe that Topaasia Cards excels at fostering productive dialogue. As each proposition in the card games is group arbitrated, the desire to win is re-appropriated for the purpose of knowledge creation. The reflective work required for both learning and assessment of competitive learning games is thus embedded in their play. Thereby, the game scaffolds the 
creation of new organizational knowledge, and also enables its players to pinpoint information needs of which they, or even the organization as a whole, may not have been aware before.

Service design games tend to be very efficient in facilitating knowledge creation, as they encourage creative discussions, shared reflection and task-completion oriented thinking in a playful mode [7]. The Topaasia games take this further. Through their competitive-reflective mode, they on the one hand enable participants to fuse those three information needs into a single whole, making task completion, context, and information creation one integrated process. They also increase time-on-task, a factor noted as a key facet of game-based learning (e.g., [12]). At the same time, they enable fluent switching between a goal-oriented and a reflective mind-state and a playful-speculative-competitive mind state (as per [1]) when players navigate optimal play choices based on their existing organizational knowledge. Topaasia Cards exemplifies the way in which those co-exist in a learning game. Whereas organizational play tends to be focused on just efficiency, and is thus often constrained [17], design games can create a safe space for innovative exploration - and make that exploration highly enjoyable.

The expansive learning potential of these kinds of games is in providing methods for interrupting the routines of organizations by allowing players to "bring in" their existing practices and contradictions and setting up a space in which the players feel at liberty to engage in playful examination of the existing practices and modelling new solutions.

\section{Ethical Statement and Funding}

The authors have no connection to Gälliwashere excluding this particular research project.

Parts of this research were supported by grant 10-5514 from Liikesivistysrahasto.

\section{References}

1. Apter, M.J.: A Structural Phenomenology of Play. In: Kerr, J.H., Apter, M.J. (eds.) Adult Play: A Reversal Theory Approach, pp. 13--29. Swets \& Zeitlinger, Amsterdam (1991)

2. Brandt, E., Messeter, J., Binder, T.: Formatting Design Dialogues - Games and Participation. CoDesign, 4, 51--64 (2008)

3. Engeström, Y.: Learning by Expanding. An Activity-theoretical Approach to Developmental Research. Orienta-Konsultit, Helsinki (1987)

4. Engestrom, Y.: Innovative Learning in Work Teams: Analyzing Cycles of Knowledge Creation in Practice. In: Engeström, Y., Miettinen, R., Punamäki, R.-L. (eds.) Perspectives on Activity Theory, pp. 377--404. Cambridge University Press, Cambridge (1999)

5. Eriksen, M.A., Brandt, E., Mattelmäki, T., Vaajakallio, K.: Taking Design Games Seriously: Re-connecting Situated Power Relations of People and Materials. In: Proceedings of the 13th Participatory Design Conference, pp. 101--110). ACM, Windhoek (2014). 
6. Gherardi, S.: Organizational Learning: The Sociology of Practice. In: Easterby-Smith, M., Lyles, M.A. (eds.) The Blackwell Handbook of Organizational Learning and Knowledge Management, pp. $43--65$ (2011)

7. Hannula, O., Harviainen, J.T.: Efficiently Inefficient: Service Design Games as Innovation Tools. In: Morelli, N., de Götzen, A., Grani, F. (eds.) Service Design Geographies, pp. 241--252. Linköping University Electronic Press, Linköping (2016)

8. Hannula, O., Irrmann, O.: Played Into Collaborating: Design Games as Scaffolding for Service Co-Design Project Planning. Simulat. Gaming, 47, 599--627 (2016)

9. Harviainen, J.T., Vaajakallio, K., Sproedt, H. Service Design Games as Innovation Tools, Knowledge Creators, and Simulation/Games. Simulat. Gaming, 47, 559--565 (2016)

10. Kaario, P., Vaajakallio, K., Lehtinen, V., Kantola, V., Kuikkaniemi, K.: Someone Else's Shoes-Using Role-Playing Games in User-Centered Service Design. In: ServDes 2009 (2009)

11. Klapztein, S., Cipolla, C. From Game Design to Service Design: A Framework to Gamify Services. Simulat. GAming, 47, 566--598.

12. Landers, R.N., Landers, A.K.: An Empirical Test of the Theory of Gamified Learning: The Effect of Leaderboards on Time-on-Task and Academic Performance. Simulat. Gaming 45, 769--785 (2014)

13. Mainemelis, C., Ronson, S.: Ideas are Born in Fields of Play: Towards a Theory of Play and Creativity in Organizational Settings. Res. Organ. Behav. 27, 81--131 (2006)

14. Tsoukas, H.: A Dialogical Approach to the Creation of New Knowledge in Organizations. Organ. Sci. 20, 941--957 (2009)

15. Vaajakallio, K.: Design Games as a Tool, a Mindset and a Structure. Aalto University, Helsinki (2012)

16. Vaajakallio, K., Mattelmäki, T.: Design Games in Codesign: As a Tool, a Mindset and a Structure. CoDesign 10, 63--77 (2014)

17. Vesa, M., Hamari, J., Harviainen, J.T., Warmelink, H.: Computer Games and Organization Studies. Organ. Stud. 38, 273--284 (2017) 